\title{
Selection index via REML/BLUP for identifying superior banana genotypes in the central region of Goiás state, Brazil ${ }^{1}$
}

\author{
Gabriella Queiroz de Almeida ${ }^{2 *} \mathbb{D}$, Juliana de Oliveira Silva ${ }^{3}$, Marcos Deon Vilela de Resende ${ }^{4}$, \\ João Luiz Palma Meneguci ${ }^{5}$, Glays Rodrigues Matos ${ }^{6}$
}

$10.1590 / 0034-737 X 201966010004$

\begin{abstract}
This study had the aim of evaluating 15 agronomic characters of 23 banana genotypes of the Cavendish, Prata, Prata-Anã, Pacovan, Mysore and Maçã groups, in three production cycles, in the climatic conditions of the central region of Goiás state, Brazil, identifying superior cultivars. The treatments were arranged in a completely randomized design, with replicates varying from 3 to 18 clones according to the availability of seedlings. Because of the unbalanced data, the components of variance were estimated using the mixed model methodology. In order to identify the superior genotypes, the predicted mean genotypic values were taken into account. The FHIA-02 (Cavendish group), PA42-44 (Prata Anã group) and FHIA-18 (Prata Anã group) genotypes presented the highest flowering precocity. The Bucanero, FHIA-17 (Cavendish group) and Grande Naine genotypes were the most productive. The Grande Naine, FHIA-17 and FHIA-02 genotypes presented the lowest sizes, and the FHIA-17, Bucanero and PV79-34 (Hybrid Pacovan) genotypes the largest pseudo stems circumferences. The genotypes with the lowest mortality rates were the Pacovan, Garantida (group Prata) and Calipso. Based on the multi-trait selection index, it was concluded that the FHIA-17, Grande Naine, Bucanero, and FHIA-02 genotypes were the most promising cultivars for production in the central region of Goiás due to their agronomic characters and high yield.
\end{abstract}

Keywords: Musa spp.; agronomical traits; clones, production; selection.

\section{RESUMO}

\section{Índice de seleção via REML/BLUP para a escolha de genótipos superiores de bananeira na região central de Goiás}

Este trabalho teve como objetivo avaliar 15 caracteres agronômicos de 23 genótipos de bananeira dos grupos Cavendish, Prata, Prata-Anã, Pacovan, Mysore e Maçã, em três ciclos de produção, nas condições climáticas da região central de Goiás, Brasil, a fim de identificar os melhores cultivares para essa região. Os tratamentos foram dispostos em delineamento inteiramente casualizado, com repetições variando de 3 a 18 clones de acordo com a disponibilidade de mudas. Por se tratar de dados desbalanceados os componentes de variância foram estimados utilizando a metodologia de modelos mistos. Com o intuito de identificar os genótipos superiores foi levado em consideração os valores genotípicos médios preditos. Os genótipos FHIA-02 (grupo Cavendish), PA42-44 (grupo Prata Anã) e FHIA-18 (grupo Prata Anã), apresentaram maior precocidade de floração. Os genótipos Bucanero, FHIA-17 (grupo Cavendish) e Grande Naine foram os mais produtivos. Os genótipos Grande Naine, FHIA-17 e FHIA-02 apresentam os menores portes e os genótipos FHIA-17, Bucanero e PV79-34 (híbrido de Pacovan) as maiores circunferências do pseudocaule.

\footnotetext{
Submetted on April 12 $2^{\text {nd }}, 2018$ and accepted on January $31^{\text {st }}, 2019$.

${ }^{1}$ This work is part of the Breeding Musa Project of Embrapa

${ }^{2}$ Universidade Federal de Viçosa, Departamento de Fitotecnia, Viçosa, Minas Gerais, Brazil. gabriellaqueirozalmeida@ hotmail.com

${ }^{3}$ Universidade Federal de Goiás, Escola de Agronomia, Goiânia, Goiás, Brazil. juholiveira13@hotmail.com

${ }^{4}$ Embrapa Floresta, Colombo, Paraná, Brazil. marcos.deon@gmail.com

${ }^{5}$ Embrapa Produtos e Mercado, Sinop, Mato Grosso, Brazil. joaomeneguci@embrapa.br

${ }^{6}$ Embrapa Arroz e Feijão, Santo Antônio de Goiás, Goiás, Brazil. glays.matos@embrapa.br

*Corresponding author:gabriellaqueirozalmeida@hotmail.com
} 
Os genótipos com as menores taxas de mortalidade foram Pacovan, Garantida (grupo Prata) e Calipso. Com base no índice de seleção, conclui-se que os genótipos FHIA-17, Grande Naine, Bucanero e FHIA-02 foram os mais promissores para serem produzidos na região central de Goiás, por apresentarem alta produtividade e caracteres agronômicos demandados pelos produtores.

Palavras-chave: Musa spp.; características agronômicas; clones; produção; seleção.

\section{INTRODUTION}

Bananas are one of the most consumed fruits in the world. They are cultivated in more than 150 countries. Bananas are the sixth most important global food product (FAO, 2016). Brazil is a major banana producer. It holds the fifth place in world production (FAOSTAT, 2017), with an estimated production of 6,962,134 tons, which covers an estimated area of 516,980 hectares (IBGE, 2017).

Relatively few banana cultivars have been transferred from their Southeast Asia origin. This has resulted in a diversity decline of these plants, as they were taken from Asia to Africa and ultimately to the Americas. Thus, several banana trees genetic breeding programs have been created to expand their genetic base, mainly due to their susceptibility to diseases such as Black Sigatoka and Panama (Martin et al. 2016). Among them, we highlight the Brazilian Program for Banana Genetic Breeding, which is coordinated by Embrapa Mandioca and Fruticultura and was founded in 1976. This program aims the development of banana cultivars of the Prata, and Maçã types, which would be resistant to the main diseases of the crop (Weber et al., 2017). As a result of this program, different cultivars were made available to farmers (Weber et al., 2017), Castricini et al. 2017).

Genotypes of the breeding program need to be characterized and evaluated in different production soil, and climate conditions (Silva et al. 2016), which is relevant for evaluating agronomic characteristics, and for allowing the identification of promising cultivars for inclusion in breeding programs or technical indication to producers. Thus, several studies have been carried out on different soils and climates (Silva et al., 2006 and 2016, Pimentel et al., 2010, Marques et al. 2011, Borges et al., 2011 and 2014, Ribeiro et al., 2012, Mendonça et al., 2013).

The aim of this study was to evaluate the performance of 23 banana genotypes from the Cavendish, Prata, PrataAnã, Pacovan, Mysore and Maçã groups during three production cycles. In addition, it aimed to evaluate the agronomic and productive characters of resistant cultivars and the incidence of main diseases which are harmful to the banana trees, in the climatic conditions of the central region of Goiás, Brazil.

\section{MATERIAL AND METHODS}

The experiment was carried out at Embrapa Products and Markets Unit, located in Goiânia (Goiás state, Brazil). The period between flowering (2008) and the third production cycle (2010) was evaluated. Temperatures ranged from $16^{\circ} \mathrm{C}$ to $31^{\circ} \mathrm{C}$ in 2008 , from $17^{\circ} \mathrm{C}$ to $30^{\circ} \mathrm{C}$ in 2009 , and from $17^{\circ} \mathrm{C}$ to $31^{\circ} \mathrm{C}$ in 2010 , with annual rainfall of $1726 \mathrm{~mm}$ and average relative humidity (ARH) of 74\% in 2008, $1577 \mathrm{~mm}$ and $70 \% \mathrm{ARH}$ in 2009, and $1240 \mathrm{~mm}$, and 65\% ARH in 2010 (Evaporimetric Station, 2015).

The micro propagated seedlings from Embrapa Cassava and Tropical Fruit (Table 1) were transplanted to the field, in a previously prepared area, with a spacing of $2.5 \mathrm{x}$ $3.0 \mathrm{~m}$. Organic fertilization was carried out with 10 liters of tanned bovine manure and phosphate fertilization (single superphosphate) with $40 \mathrm{~g}$ of $\mathrm{P}_{2} \mathrm{O}_{5}$ per pit in the planting. Thirty days after the initial plating, nitrogen and potassium fertilization (20-00-20) with $45 \mathrm{~g}$ of $\mathrm{N}$ and $45 \mathrm{~g}$ of $\mathrm{K}_{2} \mathrm{O}$ per plant was carried out. The management practices carried out during the three production cycles were: complementary irrigation, weed control, pest control, removal of dry leaves, elimination of shoots (leaving only two) at the time of flowering, and elimination of the heart and pseudo stems cut after harvest.

The genotypes were arranged in a completely randomized design, with 23 treatments with replicates varying from 3 to 18 clones according to the availability of seedlings. Since the date are unbalanced, the components of variance were estimated using the mixed model methodology, which uses REML/BLUP (Restricted Maximum Likelihood/Best Linear Unbiased Prediction) method. Considering the model, $\mathrm{y}=\mathrm{Xm}+\mathrm{Zg}+\mathrm{Ti}+\mathrm{y}$, where $y$ is the data vector, $m$ is the vector of measurements effects (assumed as fixed) added to the general mean, $g$ is the genotypic effects vector (assumed as random), $\mathrm{i}$ is the interaction effects vector (genotypes x measurements), and $\mathrm{e}$ is the error vector (assumed as random), the uppercase letters represent the incidence matrices for these effects (Resende, 2002). For this analysis, Model 55 of Selegen software, which is a repeatability model, was used (Resende, 2016). 
The following characters were evaluated: plant mortality (M); days from planting to flowering (DPF); number of living leaves in flowering (NLF); number of shoots (NS), which was counted at the moment of flowering; height of the plant in centimeter (HP), which was also measured at the moment of flowering with the aid of a flexible steel tape measure, positioned at ground level and measuring up to the leaf rosette (insertion point of the peduncle in the pseudo stems); circumference of the pseudo stems in centimeter (CPC), which was measured with a tape measure at $20 \mathrm{~cm}$ above ground level; mass of the bunch in kilos (MB); mass of the hands in kilos (MH); average weight of the fruits in grams (AWF), by weighing the second hand and the penultimate hand; number of hands (NH); number of fruits (NF); length (LF), and average diameter (DF) of the fruits in centimeters located at the center of the hands that were weighed, these measurements were made with the aid of an analog pachymeter; days from flowering to harvest (DFH); number of living leaves (NLH) at harvest time.

In order to identify the superior genotypes for each evaluated character, it was considered: the predicted mean genotypic values $(\mathrm{u}+\mathrm{g}+\mathrm{gem})$, which refers to the average genotype value over several years and capitalize an average interaction which comprises the three years of the evaluation; the heritability of genotype averages (broad sense); the genotypic values prediction accuracy (accuracy in genotype selection), based on the three years of measurements and the repeatability coefficient.

With the purpose of suggesting the best genotypes to be grown in the central region of Goiás state, considering all the characters, the multitrait selection index (model 101 of Selegen software) was used. Two alternative approaches were applied (Resende, 2002), the Active index, in which the character weights are given, and the Medium Rank index, adapted from Mulamba \& Mock, in which the genotypic values are classified for each character and the average of the rankings of each genotype for all characters is presented as the final result. For the calculation of the indices, the NLL and NF characters were considered null because they did not present a significant genotypic variance, for M, DPF, HP and, DFH the lowest predicted genotypic values were considered, and the for the remaining characters, the highest predicted genotypic values were taken into account. The accuracy was used as weights in the Active index because it represents the reliability of the characters for selecting the best genotypes.

\section{RESULTS AND DISCUSSION}

A significant variance was observed among the evaluated genotypes for most of the characters, except for NLF and NS, therefore, they did not enter the multitrait

Table 1: Genotypes evaluated from Embrapa Mandioca and fruticulture Tropical

\begin{tabular}{lcccc}
\hline Genotypes & Treatment & Number of repetitions & Genome & Genealogy (Origin) \\
\hline Caipira & 12 & 18 & AAA & Cultivar (Africa Ocidental) \\
Calipso & 7 & 3 & AAAA & Hybrid High Gate (Jamaica) \\
Bucanero & 16 & 18 & AAAA & Hybrid High Gate (Jamaica) \\
FHIA-02 & 23 & 18 & AAAA & Cavendish Hybrid (FHIA) \\
FHIA-17 & 20 & 18 & AAAA & Cavendish Hybrid \\
Thap Maeo & 6 & 18 & AAB & Cultivar type Mysore (Tailand) \\
FHIA-01 (Maravilha) & 3 & 18 & AAAB & Prata Anã Hybrid (FHIA) \\
FHIA-18 & 10 & 18 & AAAB & Prata Anã Hybrid (FHIA) \\
PA42-44 & 13 & 18 & AAAB & Prata Anã Hybrid (FHIA) \\
PA94-01 & 21 & 15 & AAAB & Prata Anã Hybrid - Embrapa \\
ST42-08 (Garantida) & 19 & 18 & AAAB & Prata Hybrid (Embrapa) \\
PV42-53 (Pacovan Ken) & 1 & AAAB & Pacovan Hybrid (Embrapa) \\
PV42-142 (Japira) & 9 & 18 & AAAB & Pacovan Hybrid (Embrapa) \\
PV42-81(Vitória) & 11 & 9 & AAAB & Pacovan Hybrid (Embrapa) \\
PV79-34 & 14 & 9 & AAAB & Pacovan Hybrid (Embrapa) \\
PV94-01 & 8 & 18 & AAAB & Pacovan Hybrid (Embrapa) \\
YB42-21 (Tropical) & 22 & 18 & AAAB & Yangambi Hybrid - type Maçã (Embrapa) \\
YB42-03 & 5 & 18 & AAAB & Yangambi Hybrid - type Maçã (Embrapa) \\
YB42-07 & 17 & 18 & AAAB & Yangambi Hybrid - type Maçã (Embrapa) \\
Maçã & 4 & 18 & AAB & Cultivar (Brazil) \\
Grande Naine & 15 & 18 & AAA & Cultivar Cavendish \\
Pacovan & 18 & 18 & AAB & Cultivar (Northeast Brazil) \\
Prata Anã & 2 & 18 & Cultivar (Santa Catarina state, Brazil) \\
\hline & & &
\end{tabular}

Rev. Ceres, Viçosa, v. 66, n.1, p. 026-033, jan/fev, 2019 
selection index because they were not able to differentiate the genotypes. For the interaction (years x genotype), no significant variance was detected for NS and DFH characters (Table 2), which demonstrates that, for these characters, a single measurement would be sufficient. Arantes et al. (2017), did a similar study and also found significant differences among treatments and cycles, with the exception of the flowering period.

All the characters presented low heritability, which indicates that they are quantitative and very influenced by the environment (Table 3 ). Considering a repeatability greater than $40 \%$ and accuracy greater than $60 \%$, it is possible to identify, through the average genotypic value (Table 3), the superior genotypes for each character that presented significant variance among the treatments.

The Maçã (4), Bucanero (16), and FHIA-17 (20) genotypes demonstrated the highest mortality rate, while the Calypso (7), Pacovan (18), and Garantida (19) genotypes presented the lowest mortality rate. The avarage number of days from planting to flowering (DPF) ranged from 448.3 to 618.4, with the YB42-07 (17) genotype being the latest and the Maçã (4) genotype the earliest (Table 2). These characters presented a low repeatability, but with selective accuracy above $50 \%$ and $60 \%$ respectively. Based on predicted genetic values, the genotypes with the lowest mortality rates were Pacovan (18), Garantida (19), and Calipso, which shows that they were the least affected by the pests and diseases of the region. The FHIA-02, PA42- 44 (13), and FHIA-18 (10) genotypes presented higher precocity of flowering (Table 3). The precocity of flowering is an important characteristic because it reduces the exposure time to pathogens, and is able to increase the number of living leaves at the floral differentiation stage, and to favor a greater amount of female flowers during the inflorescence, which results in clusters with greater number of fruits (Robinson \& Galán Saúco, 2010). Arantes et al. (2017) found the FHIA-18 and Pacovan cultivars were the earliest at the flowering stage and the FHIA-23 and FHIA-17 cultivars were the latest.

In the evaluation of plant height (Table 2), the Grande Naine (15) genotype demonstrated the lowest mean (HP = $262.2 \mathrm{~cm}$ ), followed by FHIA-02 (23) and Calipso (7). The highest observed averages were of the Garantida (HP = $413.7 \mathrm{~cm}$ ), Vitória (11), and Japira (9) genotypes. Similarly, Arantes et al. (2017) found that the highest cultivars in all cycles were the Japira, Pacovan-Ken, and JV42-135 genotypes, and the shortest ones were the Grande Naine and Caipira genotypes. On the other hand, Nomura et al. (2016) found, in the Ribeira Valley, high pseudo stems height values $(>4.5 \mathrm{~m})$ in the Caipira cultivar, which is considered a substitute for Maçã cultivar. According to Santos et al. (2006), the ideal height range for commercial bananas, is between 2.0 and $3.5 \mathrm{~m}$.
The height of the plant influences planting spacing and density, and consequently, the productivity Furthermore, it is an important feature in genotypes selection, since high cultivars are not desirable because they are of difficult harvest, the breaking of the pseudo stem, and the tipping over of plants (Santos et al., 2006). These are recurrent problems in the Pacovan genotype and their descendants (Azevedo et al., 2010). Thus, smaller sizes such as those found, based on the genotypic values (Table 3), for the Grande Naine (15), FHIA-17 (20), and FHIA-02 (23) genotypes, are the most desirable, especially in strong winds regions, since they benefit productivity avoiding damages to the bunches.

The FHIA-17 (20) genotype showed the highest pseudo stems circumference mean $(\mathrm{CPC}=79.19 \mathrm{~cm})$, while Caipira (12) genotype showed the lowest mean (CPC = $52.90 \mathrm{~cm}$ ) (Table 2). Arantes et al. (2017) and Nomura et al. (2016) also found low pseudo stems circumference values for the Caipira cultivar. The pseudo stems circumference is related to the vigor of the plant. The more vigorous the plant, the greater its ability to support the bunches and the lower is the susceptibility to tipping (Silva et al., 2011). In view of this, FHIA-17, Bucanero (16) and PV79-34 (14) are the most appropriate agronomically sized genotypes (Table 3).

At harvesting period, the highest number of living leaves (NLH) was observed in the PA42-44 (13) genotype and the lowest number in the Vitória (11) genotype. Differently from what was related by Arantes et al. (2017), who found the Prata-Anã cultivar to have the highest number of living leaves and the Garantida cultivar the lowest number of living leaves at the time of harvest. The size of the fruits is positively correlated with the number of living leaves present until harvesting time (Oliveira et al. 2013). In this study, it was possible to observe this because the genotype with the highest number of living leaves, PA42-44 (13), was one with the highest fruit weight mean, length, and diameter (Table 2).

The banana yield was correlated with the characters of the bunches, and the FHIA-17 (20) genotype showed the highest mean $(\mathrm{MB}=28.60 \mathrm{~kg}$ and $\mathrm{MH}=10.87 \mathrm{~kg})$, while Tropical (22) presented the lowest mean $(\mathrm{MB}=$ $26.33 \mathrm{~kg}$ and $\mathrm{MH}=10.05 \mathrm{~kg}$ ). The mass of the bunch is an important factor in banana productivity, but it cannot be solely considered for genotype selection, since other characters also influence this selection, such as the characters related directly to the fruit, such as size, weight, and shape. In this way, and based on the genotypic values (Table 3), we were able to highlight the following genotypes: Bucanero, FHIA-17, and Grande Naine, with the heavier bunches; Bucanero, FHIA17, and Grande Naine, with the heavier hands; Thap Maeo (6), FHIA-17, and FHIA-02, with the highest number of 


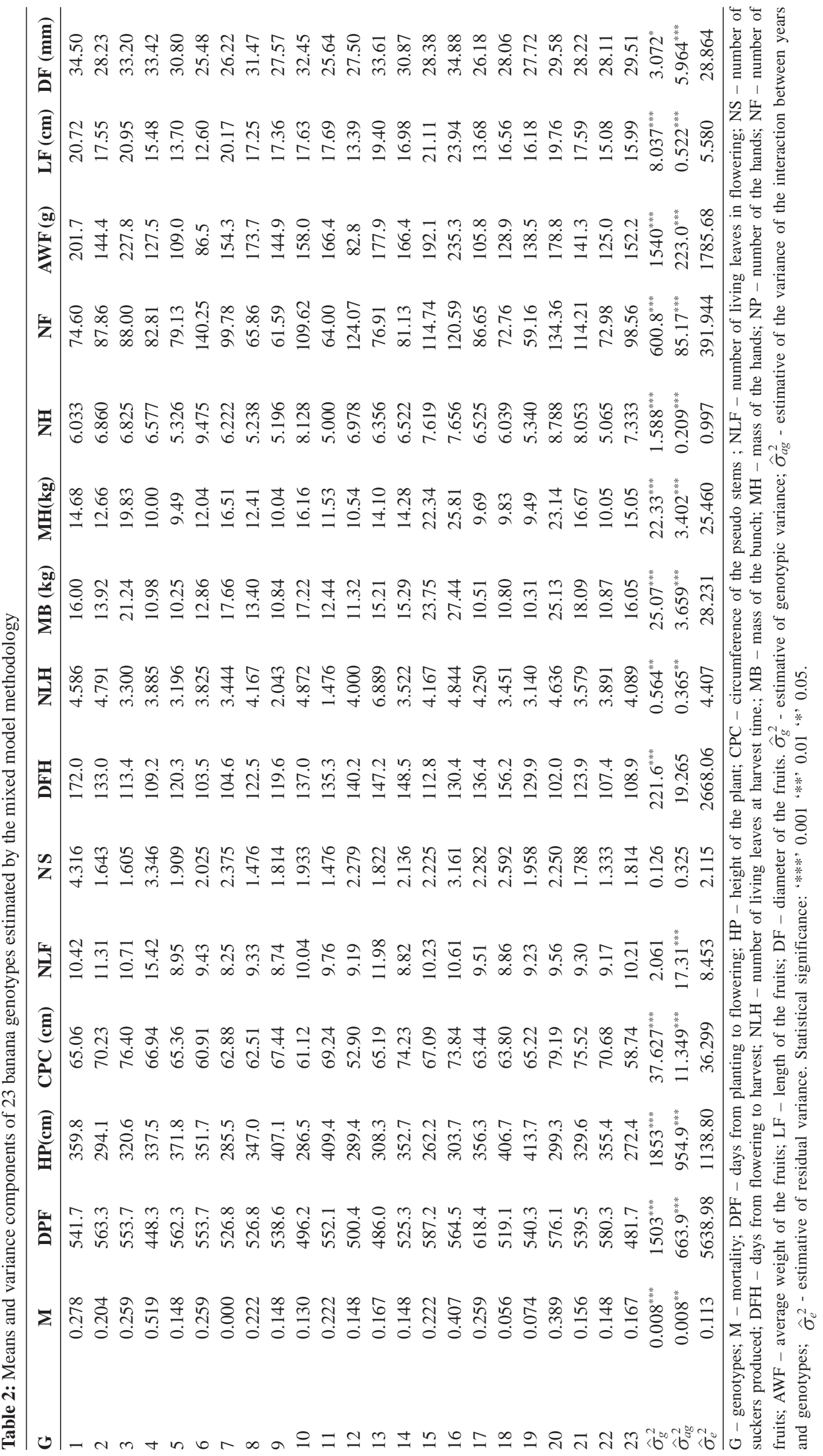

Rev. Ceres, Viçosa, v. 66, n.1, p. 026-033, jan/fev, 2019 


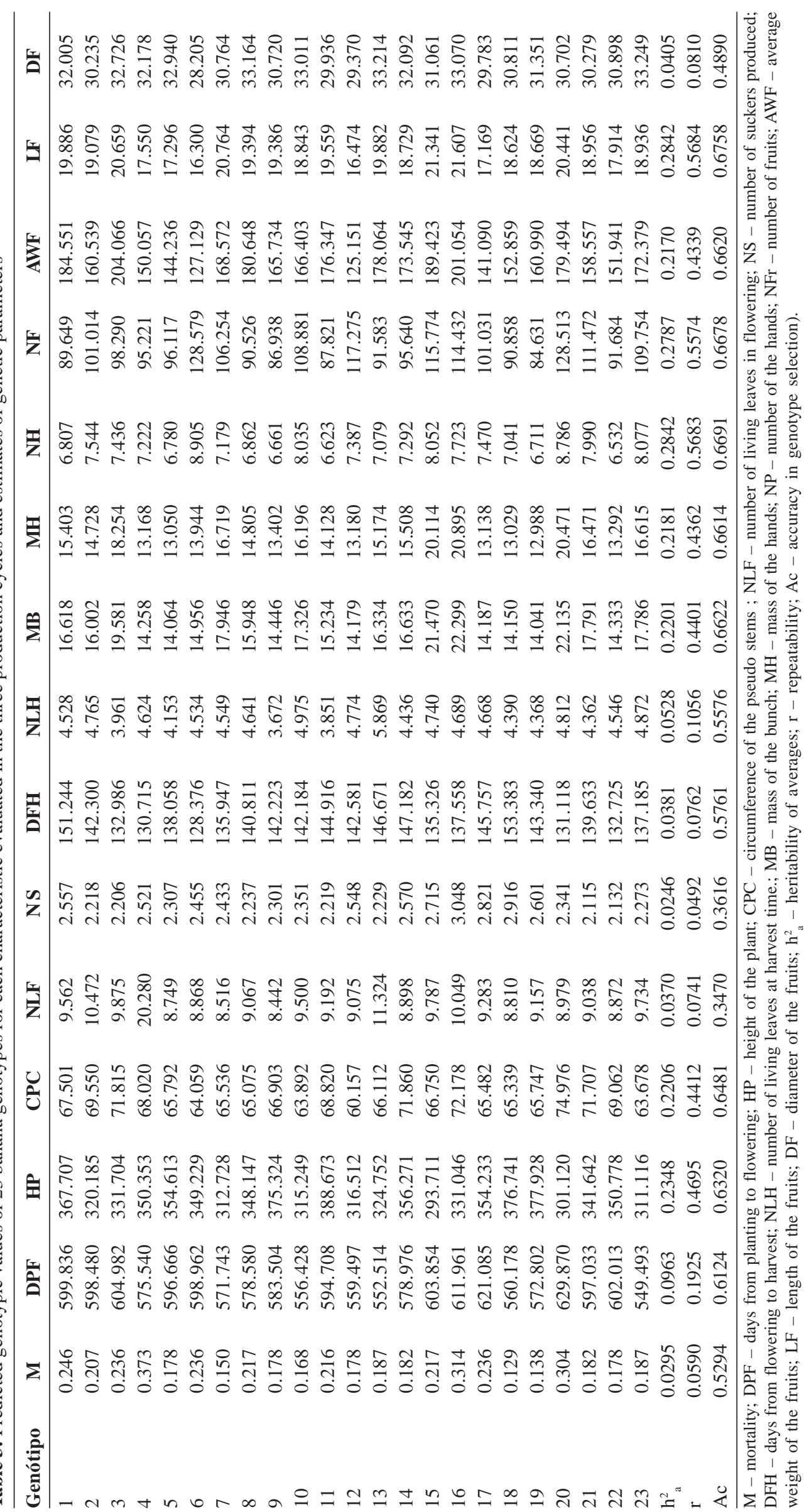


Table 4: Medium Rank selection index (left) and Active selection index (right) of 23 banana genotypes evaluated

\begin{tabular}{lccccccccc}
\hline Order & Genotype Medium Rank & Gain & Gain \% & Order & Genotype & Active Index & Gain & Gain \% \\
\hline 1 & 20 & 6.9231 & 6.9231 & 73.3333 & 1 & 20 & 46.0088 & 46.0088 & 20.5209 \\
2 & 15 & 7.0769 & 7 & 71.4286 & 2 & 15 & 44.9056 & 45.4572 & 19.0759 \\
3 & 16 & 7.0769 & 7.0256 & 70.8029 & 3 & 16 & 44.8592 & 45.2579 & 18.5537 \\
4 & 23 & 7.3846 & 7.1154 & 68.6486 & 4 & 23 & 42.6237 & 44.5993 & 16.8287 \\
5 & 10 & 8.3077 & 7.3538 & 63.1799 & 5 & 3 & 42.1767 & 44.1148 & 15.5594 \\
6 & 7 & 8.4615 & 7.5385 & 59.1837 & 6 & 10 & 41.6153 & 43.6982 & 14.4682 \\
7 & 3 & 9.1538 & 7.7692 & 54.4554 & 7 & 7 & 41.2172 & 43.3438 & 13.5397 \\
8 & 13 & 9.6154 & 8 & 50 & 8 & 13 & 41.0424 & 43.0561 & 12.7862 \\
9 & 21 & 10.8462 & 8.3162 & 44.296 & 9 & 21 & 39.7752 & 42.6916 & 11.8312 \\
10 & 2 & 11.6154 & 8.6462 & 38.79 & 10 & 14 & 38.3192 & 42.2543 & 10.6859 \\
11 & 14 & 11.8462 & 8.9371 & 34.2723 & 11 & 2 & 38.1086 & 41.8774 & 9.6986 \\
12 & 8 & 11.9231 & 9.1859 & 30.635 & 12 & 8 & 37.6082 & 41.5217 & 8.7667 \\
13 & 4 & 13.6923 & 9.5325 & 25.8845 & 13 & 6 & 36.2772 & 41.1182 & 7.7099 \\
14 & 12 & 13.8462 & 9.8407 & 21.943 & 14 & 1 & 35.8677 & 40.7432 & 6.7275 \\
15 & 1 & 13.9231 & 10.1128 & 18.6613 & 15 & 4 & 35.1888 & 40.3729 & 5.7575 \\
16 & 6 & 14 & 10.3558 & 15.8774 & 16 & 22 & 35.1178 & 40.0445 & 4.8971 \\
17 & 22 & 14.3846 & 10.5928 & 13.2849 & 17 & 12 & 34.9191 & 39.743 & 4.1074 \\
18 & 9 & 15.3077 & 10.8547 & 10.5512 & 18 & 19 & 34.3126 & 39.4413 & 3.3171 \\
19 & 5 & 15.3846 & 11.0931 & 8.1752 & 19 & 5 & 34.1001 & 39.1602 & 2.5807 \\
20 & 11 & 15.6923 & 11.3231 & 5.9783 & 20 & 18 & 34.074 & 38.9059 & 1.9146 \\
21 & 18 & 16.1538 & 11.5531 & 3.8681 & 21 & 9 & 33.6961 & 38.6578 & 1.2647 \\
22 & 19 & 16.2308 & 11.7657 & 1.9911 & 22 & 11 & 33.6236 & 38.429 & 0.6653 \\
23 & 17 & 17.1538 & 12 & 0 & 23 & 17 & 32.5877 & 38.175 & 0 \\
\hline & & & & & & & & & \\
\hline
\end{tabular}

hands; Thap Maeo, FHIA-17, and Caipira (12), with the highest number of fruits; FHIA-01 (3), Bucanero, and Grande Naine, with the highest average fruit weight; Bucanero, Grande Naine, and Calipso (7), with the largest length of the fruits.

The two methodologies for calculating the multitrait selection index (Table 4) presented the same four first genotypes, however they presented different gain values due to the difference between the methodologies. Since in the Active index it is necessary for assigning weight (precision between 0 and 1) for each character, which reduces the percentage of the gain; in the index of Medium Rank selection it is not necessary to attribute weight to the characters, which increases gains percentage. Regardless of the gain presented by the two methodologies, the FHIA-17, Grande Naine, Bucanero, and FHIA-02 genotypes, in this order, proved to be the most productive and with the most desired agronomic characters. The Bucanero cultivar was also recommended by Lédo et al. (2018) based on physical-chemical characters of the fruits of thirteen banana genotypes, to be cultivated in coastal flat regions. The Grande Naine cultivar has shown great performance according to Patel et al. (2018), who reports a constant increase in banana production and productivity in India, due to the adoption of this variety and other Cavendish clones. According to Nomura et al. (2017), the FHIA-17 cultivar has great potential for introduction into the Brazilian production system for showing characteristics similar to the Grand Naine cultivar. According to Weber et al. (2017) the FHIA 02 cultivar shows an adequate profile and high yield potential, which can be an alternative to the traditional Prata subgroup.

\section{CONCLUSION}

The FHIA-02 (23) from the Cavendish group, PA42-44 (13) and FHIA-18 (10) from the Prata Anã group are the most precocious genotypes. The genotypes with lowest mortality rates are: Pacovan (18), Garantida (19) from the Prata group, and Calipso (7). The FHIA-17 (20) genotype is the most productive, along with Bucanero (16) and Grande Naine (15). The Grande Naine and FHIA-02 (23) genotypes have the smaller in size. The Bucanero and PV79-34 genotypes possess the highest pseudo stems circumference.

The FHIA-17, Grande Naine, Bucanero, and FHIA-02 genotypes are the most promising for the central region of Goiás and they can adapt well to other regions of similar climate.

The indexes used (Medium Rank and Active) are concordant with the selection of the first four genotypes. However, they are discordant with the magnitude of the expected gain. 


\section{ACKNOWLEDGEMENTS}

We are thankful to Embrapa Products and Market. To the researchers, technicians and trainees who participated in the project.

\section{REFERENCES}

Arantes A de M, Donato SLR, Silva TS, Rodrigues Filho VA \& Amorim EP (2017) Agronomic evaluation of banana plants in three production cycles in southwestern state of Bahia. Revista Brasileira de Fruticultura, 31:01-12.

Azevedo VF, Donato SLR, Arantes AM, Maia VM \& Silva SO (2010) Avaliação de bananeira tipo prata, de porte alto, no semiárido. Ciência e Agrotecnologia, 34:1372-1380.

Borges CV, Amorim VBO, Ramlove F, Ledo CAS, Donato M, Maraschinc M \& Amorim EP (2014) Characterization of metabolic profile of banana genotypes, aiming at biofortified Musa spp. cultivars. Food Chemistry, 145:496-504.

Borges RS, Silva SO, Oliveira FT \& Roberto SR (2011) Avaliação de genótipos de bananeira no norte do estado do Paraná. Revista Brasileira de Fruticultura, 33:291-296.

Castricini A, Dias MSC, Rodrigues MGV \& Oliveira PM (2017) Quality of organic banana produced in the semiarid region of Minas Gerais, Brazil. Revista Brasileira de Fruticultura 39:01-07.

Evaporimetric Station (2015) Escola de Agronomia, da Universidade Federal de Goiás. Available from: https:// www.agro.ufg.br/p/7944-estacao-evaporimetrica. Accessed from: 30 october 2015

IBGE (2017) Levantamento sistemático de produção agrícola Available from: http://www.ibge.gov.br/home/estatistica/indicadores/agropecuaria/lspa/default_publ_completa.shtm. Accessed from: 10 April 2017.

FAO (2016) FAO database In: Food and Agriculture Organization Of the United Nations. Available from: http://faostat3.fao.org/ download/Q/QC/E. Accessed from: 20 May 2016.

FAOSTAT (2017) Food and Agricultural Organization. Available from: http://faostat3.fao.org/home/E. Accessed from: 10 April 2017.

Lédo AS, Silva TN, Martins CR, Silva AVC, Lédo CAS \& Amorim EP (2018) Caracterização físico-química de frutos de bananeira por procedimentos uni e multivariados. Bioscience Journal, $34: 24-33$

Marques PRR, Donato SLR, Pereira MCT, Coelho EF \& Arantes AM (2011) Características agronômicas de bananeiras tipo Prata sob diferentes sistemas de irrigação. Pesquisa Agropecuária Brasileira, 46:852-859.

Martin G, Baurens FC, Droc G, Rouard M, Cenci A, Kilian A, Hastie A, Dole•el J, Aury JJM, Alberti A, Carreel F \& D'Hont A (2016) Improvement of the banana "Musa acuminata" reference sequence using NGS data and semi-automated bioinformatics methods. BMC GENOMICS, 01:02-12.

Mendonça KH, Duarte DAS, Costa VAM, Matos GR \& Seleguini A (2013) Avaliação de genótipos de bananeira em Goiânia, estado de Goiás. Revista Ciência Agronômica, 44:652-660.

Nomura ES, Cuquel FL, Damatto Junior ER, Fuzitani EJ, Borges AL \& Saes LA (2016) Nitrogen and potassium fertilization on 'Caipira' and 'BRS Princesa' bananas in the Ribeira Valley. Revista Brasileira de Engenharia Agrícola e Ambiental, 20:702-708.
Nomura ES, Cuquel FL, Damatto Junior ER, Fuzitani EJu \& Borges AL (2017) Fertilization with nitrogen and potassium in banana cultivars 'Grand Naine', 'FHIA 17' and 'Nanicão IAC 2001' cultivated in Ribeira Valley, São Paulo State, Brazil. Acta Scientiarum. Agronomy, 39:505-513.

Oliveira JM, Coelho Filho MA \& Coelho EF (2013) Crescimento da bananeira Grande Naine submetida a diferentes lâminas de irrigação em tabuleiro costeiro. Revista Brasileira Engenharia Agrícola e Ambiental, 17:1038-1046.

Patel MJ, Sitapara HH, Shah NI \& Patel HR (2018) Effect of different levels of planting distance and fertilizers on growth, yield and quality of banana cv. Grand Naine. Journal of Pharmacognosy and Phytochemistry, 07:649-653.

Pimentel RM de A, Guimarães FN, Santos VM dos \& Resende JCF de (2010) Qualidade pós-colheita dos genótipos de banana PA42-44 e Prata Anã cultivados no norte de Minas Gerais. Revista Brasileira de Fruticultura, 32:407-413.

Resende MDV de (2002) Genética biométrica e estatística no melhoramento de plantas perenes. Brasília, Embrapa Informação Tecnológica. 975 p.

Resende MDV de (2016) Software Selegen-REML/BLUP: a useful tool for plant breeding. Crop Breeding and applied Biotechnology, $16: 330-339$

Ribeiro LR, Oliveira LM de, Silva SO \& Borges AL (2012) Caracterização física e química de bananas produzidas em sistemas de cultivo convencional e orgânico. Revista Brasileira de Fruticultura, 34:774-782

Robinson JC \& Galán Saúco V (2010) Bananas and platains. 2ª ed. Oxford: CAB International. 311p. (Crop Production Science in Horticulturae Series, 19)

Santos SC, Carneiro LC, Silveira Neto NA, Paniago Junior E, Freitas HG \& Peixoto CN (2006) Caracterização morfológica e avaliação de cultivares de bananeira resistente a Sigatoka negra (Mycosphaerella fijiensis Morelet) no sudoeste goiano. Revista Brasileira de Fruticultura, 28:449-453.

Silva EA, Boliani AC \& Corrêa LS (2006) Evaluation of banana (Musa $\mathrm{sp}$ ) cultivars in Selvíria -MS region. Revista Brasileira de Fruticultura, 28:101-103.

Silva MJR, Jesus PRR, Anjos JMC, Machado M \& Ribeiro VGR (2016) Caracterização agronômica e pós-colheita das bananeiras 'Maravilha' e 'Preciosa' no Submédio do Vale São Francisco. Revista Ceres, 63:46-53.

Silva S de O, Matos AP de, Cordeiro ZJM, Lima MJC \& Amorim EP (2011) Avaliação de genótipos tetraploides de bananeira cultivados em área infestada pelo agente causal do mal do panamá. Revista Brasileira de Fruticultura, 33:125 132.

Weber OB, Garruti DS, Norões NP \& Silva SO (2017) Performance of banana genotypes with resistance to black leaf streak disease in Northeastern Brazil. Pesquisa Agropecuária Brasileira, 52:161-169. 